\title{
REFLECTIONS ON THE DEVELOPMENT IN BRITAIN OF INTERDISCIPLINARY APPROACHES TO LAW: UTILITY AND DISUTILITY
}

\author{
Anthony Ogus, Professor of Law, University of Manchester, University \\ of Maastricht ${ }^{1}$

\section{INTRODUCTION}

Over twenty-five years have elapsed since the Social Science Research Council (now the Economic and Social Research Council) first became interested in developing collaboration between social sciences and the law. It seems an appropriate time to reflect on how interdisciplinary approaches to law have evolved ${ }^{2}$ and, given the forthcoming annual conference of the Socio-Legal Studies Association at Belfast, this journal is a fitting outlet.The paper proceeds on the assumption that the approaches need no longer to be justified. Its title is intended simply to indicate that within the huge body of work which has accumulated there have inevitably been major variations in quality and usefulness and I have set myself the task of trying to explain how and why such variations should have occurred. At the heart of the "utility of research" issue there is a tension between the two traditional wings of interdisciplinary research: on the one hand that which involves high theory or much abstract modelling; and, on the other, that which is empirically based or at least is designed to answer hard policy questions. An important goal of research management and financing is the optimal mix of these two approaches: for the discipline or sub-discipline to be advanced, scholars must have "space" in which to develop the theoretical tools. At the same time, there should be measurable returns on the investments in theoretical developments, in the sense of the research findings being used to facilitate understanding or to guide policy choice.

My sense is that, in the first half of the period under review, there was an unhealthy obsession with high theory and abstraction; in the last decade or so the pendulum has beneficially swung in the other direction. To understand these developments, ${ }^{3}$ it is necessary to relate them to the changing conditions of the academic marketplace.

1 A revised version of a paper presented at the Israeli Science Foundation Research Workshop on Empirical Research and Legal Realism - Setting the Agenda, University of Haifa, June 1999. I am grateful for the comments of participants at the workshop and for the helpful suggestions of a referee.

2 Several collections of essays on the topic have recently been published. See especially: ESRC, Review of Socio-Legal Studies: Final Report (1994); Galligan (ed), Socio-Legal Studies in Context: The Oxford Centre Past and Present (1995); Thomas (ed), Legal Frontiers (1996); Thomas (ed), Socio-Legal Studies (1997).

3 As has been pointed out to me by a referee, there may be interesting parallels with developments in the American law schools in the 1930s. There the revolt against formalism led to much interest in social science methodology, although involvement in empirical research did not endure: Duxbury, Patterns of American Jurisprudence (1995), pp. 90-97. 


\section{LEGAL INTERDISCIPLINARY STUDIES: THE FIRST WAVE}

If I take as my first period that from 1972 (the founding of the Oxford Socio-Legal Centre) to about 1984, how should it be characterised? It was a period in which

"social science and scientists were drawn into socio-legal research as the handmaidens of largely disaffected lawyers. These lawyers in turn saw socio-legal work as a means of escaping from what they regarded as the increasingly socially irrelevant and narrow intellectual confines of traditional legal and jurisprudential theory and research."4

Many pursued their work from a deep conviction that law which purported to be neutral and available to all was in fact systematically biased towards wealth and privilege. They saw their task as exposing the reality beneath the surface. These were the times when Marxism made its greatest impact on the British law schools and there was much talk of commodification and the "withering away" of law. The writings of Pashukanis seemed, for ever, to be the flavour of the month. The impetus for critical legal scholarship, as it came to be called, was then primarily political. In Alan Hunt's words,

"many proponents wish to espouse an explicit political commitment in that their work seeks to contribute towards some political goal. A typical formulation expresses a commitment to overcoming "domination" and "hierarchy". This concern involves a rejection . . . of the prevalent apolitical stance of much legal scholarship founded on the belief or in the possibility of value neutrality which portrays the lawyer as technical expert." 5

There were benefits to such an approach. "Law in context" or the "living law" was seen to have contemporary significance; we could at last relate our legal studies to the intellectual climate of the decade. And yet did not this obsession with social justice reveal only a partial vision of how the application of social science theory could enrich our understanding of law? The understandable intellectual reaction against the stifling dullness of doctrinal, "black-letter" legal scholarship might suggest that any external perspective on the law seemed to offer stimulus, but the concern seemed to focus almost exclusively on the insights provided by social theory on how legal institutions might - or more typically might not facilitate fair distributions of wealth and power. Might not other theory, say economic theory, help us to explore, say, functional relationships between legal arrangements and the creation of wealth? It was, after all, a time when there was - if not among sociologists - a general concern about the decline of the United Kingdom's industrial performance. I recall a meeting of the Social Sciences and Law Committee of the Social Science Research Council at which my fellow members seemed initially quite perplexed at my contention that our research agenda ought to include questions of how law operates as a resource-allocating device.

The ubiquitous concern with social justice did not imply a uniformity of approach. There was, indeed, a serious conflict between "sociology of law" and "socio-legal studies". 6 Those engaged in the latter attempted to

4 ESRC Review, above n.2, p.36.

5 Hunt, "The Critique of Law: What is Critical About Critical Legal Theory?" in Fitzpatrick and Hunt (eds.), Critical Legal Studies (1987), p. 6.

6 See especially Campbell and Wiles, "The Study of Law and Society in Britain" (1976) 10 Law and Society Review 547. For a critical contemporary view on this 

Law

come to grips with actual legal principles in those areas of law which centrally affected the disadvantaged or marginalised sections of the community, thus particularly criminal law and criminology, family law, mental health, welfare law, labour law. But the high theorists appeared to have the dominant voice, arguing that the work of the "empiricists" served largely to uphold the legitimacy of the established legal order.

We should not, however, forget that while those engaged in socio-legal studies may have been in the minority, they nevertheless included some powerful figures, including some who might be described as the "establishment" of legal interdisciplinary work of the period. Oliver McGregor and Donald Harris were already senior academics with international reputations in mainstream sociology and law, respectively, when they became the first two Directors of the Oxford Socio-Legal Centre. ${ }^{7}$ They managed large and successful major research projects on family ${ }^{8}$ and accident law. ${ }^{9}$ Here we see work that was intended to put British socio-legal work on the map and to convince doubters that, given the significant impact which it could make on policy-making, it deserved generous public funding. There was not an expectation that the work would necessarily and immediately influence policy developments; rather, the information acquired and the ideas advanced would fuel the debate and indicate possible ways forward. ${ }^{10}$ For this purpose, it was essential that publication of the research findings should use language that was easily comprehensible to those lawyers and policy-makers that were likely to be most influenced by them..$^{11}$ It is striking too that, although reputable social science methodology had been employed, the language of social science theory was carefully avoided..$^{12}$ Also, while both studies revealed major shortcomings in existing legal provision for single parents and accident victims, the mode of analysis is manifestly apolitical and impeccably free from ideological bias.

But not all interdisciplinary work followed this pattern or had so smooth a passage. Inevitably, there were in those early days some considerable problems of communication between those working with abstract, sophisticated social science theory and the legal world whose practices and principles were the subject of investigation. I recall, for example, a law-and-economics workshop in the mid-1970s at which an eminent economist rendered his theory of the "Value of Life" totally meaningless to his legal audience, because it had never occurred to him that they would be unfamiliar with mathematical exposition. I remember also, at about the same time, a not too fruitful dialogue at a Civil Procedure workshop

debate, see Hutter and Lloyd-Bostock, "Law's Relationship with Social Science: The Interdependence of Theory, Empirical Work, and Social Relevance in Socio-legal Studies" in Hawkins (ed.), The Human Face of Law: Essays in Honour of Donald Harris (1997), ch.1.

7 For an account of this period, see Hawkins, "Prologue: Donald Harris and the Early Years of the Oxford Centre" in Hawkins, above n.6, pp. 1-17.

8 See McGregor, Social History and Law Reform (1979).

9 Harris et al, Compensation and Support for Illness and Injury (1984).

10 ESRC Review, above n.2, p.17. For a more polemical view, see Mansell, "Tort and Soicio-Legal Studies. The Road to Damascus: Paved With Good Intentions But Few Epiphanies" in Thomas (1997), above n.2, pp.227-228.

11 See also Harris's "The Development of Socio-Legal Studies in the United Kingdom" (1983) 3 Legal Studies 315 which avoids jargon and presents a very empirically-orientated vision of the subject.

12 I remember an isolated reference to Durkheim appearing in an early draft of Compensation and Support, above n 9, but subsequently disappearing. 
between researchers, clad in tea-shirts and jeans, engaging in ethnomethodological analysis of social interaction in the courtroom, and an eminent Master of the Queen's Bench, in a three-piece suit, more concerned with reforming the procedures for payment into court.

This was a matter of greater import than these anecdotes might suggest. What McGregor and Harris had been quick to perceive, but what many younger scholars were reluctant, sometimes stubbornly so, to admit was that for interdisciplinary studies of law to make their impact they had to transcend the conceptual framework of the disciplinary base from which they originated. It is relatively easy to persuade those who share the same conceptual framework and language of discourse. As Posner puts it,

"The closer knit the interpretative community . . . the simpler the interpretative task. In economic terms one might say that the more homogeneous the interpretative community is, the lower are the costs of overcoming inevitable "noise" in communication."13

The task of translating "noise" into meaningful signals for those outside the cosy interpretative community was more challenging but also essential. As an example, let me take Pat Carlen's 1976 study of the magistrates' courts. The late Edward Griew's elegant review of this in the Criminal Law Review epitomises so well the problem that I am describing that I have taken the liberty of extracting a large passage from it. ${ }^{14}$

"I should not wish it to be said that I had misrepresented Dr. Carlen's theme by any clumsy attempt to state it in my own words. She puts it this way herself in her Introduction (p xi): "The argument of the book is that the justice produced in the magistrates' courts emanates from social relationships which, though they may appear to ironicise the ideal conceptions of justice as they are encapsulated in the Criminal Law, are, in this capitalistic society, socially coherent." I am not sure that I fully grasp the notion of "social relationships which . . . are . . . socially coherent." I doubt whether, if I did, I would find it inconsistent with the reality, let alone the appearance of, ironicising even a single conception of justice, ideal or otherwise, and whether or not encapsulated in the Criminal Law. I have not in fact discovered what conceptions of justice, by whomsoever entertained, are so encapsulated. Moreover, I do not quite see the relevance of the distinction between capitalist and other forms of society which is implied here and, with similar suddenness and lack of explanation, at a number of other places in the book. And plainly Dr. Carlen and I use the word "irony", with or without ingenious derivatives, in different ways. The full force of Dr. Carlen's summary of her work is therefore something of a mystery.

It is not as though this book is intended only for sociologists. "The bulk of the book is . . . written for all those who work in, or who one day might find themselves in, the magistrates' courts" (p xii) . . . All the more reason why one would expect to find careful explanations of words used in specialised ways and painstaking attention to the problem of communication with a varied audience. ...

13 Posner, “Jurisprudence of Scepticism” (1988) 86 Michigan LR 827, at p.850.

14 [1976] Criminal LR 647-648. 

Law

It is a great pity. Dr. Carlen has a very important concern - mainly (I now use my own language) the study of court processes in terms of rituals, roles, relationships, interaction, communication, control. This is indeed a subject of great significance for anyone concerned with the quality of legal operations. Legal education at every stage almost entirely neglects reference to the reality of the consumer's experience in his contact with the law, to the genuineness of his alleged choices, to the problem of real (as opposed to ritual) communication between him and his lawyer or the court. Those trained in other disciplines have to help us to wake up to these problems. We look to them to furnish tools for the humane reform of legal processes. . . . [Dr. Carlen's] work might have been the source of a host of plainly transmitted insights of great value. But, alas, if she is unread, as her prose makes inevitable, the opportunity is lost."

These are not the pedantic whinings of an old fogey. Nor do I have any reason to doubt the genuineness of the plea for more coherent work and comprehensible exposition on the same topic. The criticism is derived from a simple conviction (which I share) that insights generated by technical analysis can and must be expressed in a language which a lay person can appreciate.

If, as I would suggest, much British interdisciplinary legal scholarship of this period was hidebound in its own conceptual base, failed to penetrate the barriers between disciplines, involved dialogues only between the cognoscenti, tended towards self-indulgence and, most importantly, failed to impact on legal policy-making, why should this have occurred? I think that we must look to the academic environment at the time and, in particular, the market forces which impinged on research efforts.

Legal educational establishments were expanding rapidly in the 1970s. Given also the expansion occurring more generally in legal work at that time and that the demand for high quality academic staff probably outstripped supply, it was a reasonable assumption that young, reasonably gifted legal scholars could find tenured positions relatively easily. How they would advance their career was mostly left to their own initiatives but two messages seemed to have been assimilated. First, if you were engaged in work with another discipline, that would suggest intellectual endeavour of a high order; even more so, if you could publish papers revealing that you had a mastery of the language and concepts of that discipline. Nevertheless, secondly, you should be wary of articulating the ideas of the foreign discipline in relation to mainstream legal doctrine because you might not be understood and, in any event, that might undermine the authority of senior legal scholars working in the field along more traditional lines ${ }^{15}$ - and this might not be good for promotion prospects. The implications for the development of interdisciplinary studies in law would seem to be that progress within a particular disciplinary base would be encouraged and dialogue between those, primarily young, scholars so engaged was likely to flourish. But such work would be insulated from mainstream legal scholarship, there being little motivation to transcend the intellectual boundaries and communicate relevant research findings to those engaged in traditional doctrinal analysis.

What, then, of research funding? At that time, with the possible exception of the Home Office, there was little prospect of interdisciplinary legal scholars obtaining contracts directly from government departments for policy-related research. True, the Social Science Research Council, with

15 Cf Thomas, "Introduction" in Legal Frontiers, above n 2, at p.6. 
its newly established interest in socio-legal studies, ${ }^{16}$ had a significant amount of money available for this purpose, but it was used in ways which largely enhanced, rather than combated, the trends described above. Decisions on the grants were made by a specialist committee comprising a small group of predominantly committed scholars whose primary concern was to see the development of socio-legal studies. It had a heavy criminological bias. Alongside the research grant system, core funding on a very generous and prolonged scale was provided for the Oxford SocioLegal Centre. ${ }^{17}$ Neither the SSRC nor the Advisory Board of the Centre gave the latter any direction regarding its research objectives, and control was largely limited to ensuring that the research agenda was compatible with the Centre's terms of reference. Understandably, that was perceived to be considerably advantageous for the development of socio-legal studies because it allowed scholars, many of whom were employed on relatively prolonged research contracts, time to develop theoretical paradigms without feeling under pressure to produce "hard" research results. That did not inhibit, as we have already seen, the launching of major empirical projects with significant policy overtones, such as those on family law and compensation for accidents. But in relation to these I would repeat the observation that the main protagonists were already senior scholars in their field. They were not subject to the same incentive structures as their junior colleagues, were not concerned to establish their own legitimacy (except as being identified with the socio-legal movement) and were not going to be perceived as a threat to colleagues in the mainstream.

Let me draw some conclusions on this, the first period of interdisciplinary studies. It was an exciting era in which many of those frustrated by the intellectual and theoretical limitations of traditional, doctrinal analysis, acquired - often self-taught - new methodological approaches to law. With the notable exception of some major empirical projects undertaken mainly by senior academics, the published work tended to be highly theoretical and not easily accessible to those outside the particular discipline. If the work was also seen as being iconoclastic, that perhaps was unsurprising given the political context in which major challenges were being made to the established order both inside and outside the universities. In any event, as I have tried to demonstrate, the characteristics of interdisciplinary work were to a significant degree related to the institutional and financial structures used at that time to encourage research. As Thomas has written,

"For so long as it remained in unthreatening opposition to doctrinal legal scholarship its otherness, offered as a minority alternative, was acceptable. Its apparently unchallenging marginality ensured its untroubled existence from external scrutiny." 18

\section{LEGAL INTERDISCIPLINARY STUDIES: THE SECOND WAVE}

I take as my second period that between (about) 1985 and the present. In some respects I am ill-placed to offer reliable commentary on interdisciplinary legal studies generally. True, I am more embedded than ever in one particular branch of those studies (law-and-economics) and

16 See Hawkins, above n 7, at pp.5-9.

17 Between 1985 and 1991, ESRC funding of the Centre accounted for over a third of its total socio-legal research funding (ESRC Review, above n 2, at p.31) and it is a reasonable inference that in the earlier period this figure was even higher.

18 Thomas (1997), above n 2, at p.3. 

Law

have published surveys of British work in this area ${ }^{19}$ as well as a piece on how such work has impacted on legal thinking. ${ }^{20}$ Nevertheless, I am further removed than I was in the earlier period, ${ }^{21}$ from interdisciplinary legal research generally. In particular, I feel less than comfortable when faced with one or more of the various branches of post-modern legal scholarship. I therefore make the following observations with some diffidence.

The overriding impression is that interdisciplinary legal studies have been, during the last decade or so, a success story. The creation of the SocioLegal Studies Association (in 1990) and the current size of its membership (over 500 in 1996) (22 $^{2}$ testify to the numerical strength of this type of research. Equally striking is the degree to which interdisciplinary work has now penetrated the mainstream of legal discourse. We saw in the earlier period the strategic advantage of not "threatening" the core areas of legal scholarship and the evidence suggests that in 1974 such areas were listed as representing the interests of only 11 per cent of socio-legal researchers. By 1994 that figure had increased to 26 per cent. ${ }^{23}$ Far from being threatened, now many of the leading textbook writers and compilers of "cases and materials" in the core areas were to relish the opportunity of drawing upon interdisciplinary research to broaden their accounts of the subjects. ${ }^{24}$ And those working on family law, the legal professions, alternative dispute resolution, the criminal process and regulation, areas to which interdisciplinary studies had made a major contribution, ${ }^{25}$ could not hold themselves out as having expertise unless they were able to relate their analysis to these studies. Twining has ventured the impression that

"In both research and teaching of particular subjects within law schools, socio-legal studies have moved from barely tolerated marginality, to acceptance, to a relatively high degree of integration . . . Socio-legal studies have made significant contributions to the rethinking and reconceptualization of specialized fields of law, both traditional and new." 26

While, as we shall see, the tension between "high theory" and policyorientated research has not disappeared, nevertheless there has been an

19 Ogus, "Law and Economics in the United Kingdom: Past, Present and Future" in Galligan, above n 2, pp.26-34; Ogus and Amass, Research Review on Lawand-Economics: State of the Art and Questions for the Future, (1997), LCD Research Series No 4/97.

20 Ogus, "Law-and-Economics from the Perspective of Law" in Newman (ed.), The New Palgrave Dictionary of Economics and the Law (1998), vol.2, pp. 486-492.

21 During much of that period, I was a member of a relevant SSRC, later ESRC, Committee.

22 Thomas (1997), above n 2, at p.11.

23 Ibid, at pp.14-15, defining "core" as those required by the Law Society for exemption from Part I of the Law Society Finals (now the Common Professional Examination).

24 Some key examples of the latter from the early 1990s: Beale, Bishop and Furmston, Contract Cases and Materials ( ${ }^{\text {nd }}$ ed, 1990); Hepple and Matthews, Tort Cases and Materials (4 ${ }^{\text {th }}$ ed, 1991); Wheeler and Shaw, Contract Law (1994); Ramsay, Consumer Protection Text and Materials (1991).

25 See ESRC Review, above n 2, ch.2.

26 Twining, "Remembering 1972: The Oxford Centre in the Context of Development in Higher Education and the Discipline of Law" in Galligan, above n 2, at pp.41-42. 
increased involvement in the latter. Many of those previously oversensitive to the hostility aroused by "empiricism" have been able to accommodate themselves to the utility of "bottom-up" work by embracing theory at a "grounded or middle-range rather than a social structural level", ${ }^{27}$

Of course, this degree of penetration could not have occurred if the relevant findings of the interdisciplinary researchers had not been communicated in concepts and language which the conventional scholars were able easily to understand. The magnitude and importance of this task of acting as intermediary between what is sometimes highly sophisticated social science theory and traditional legal doctrine should not be underestimated. Let me take the example of law-and-economics, the subdiscipline with which I am most familiar. The growth of abstract work in this area by American economists has been spectacular, so much so that it is now difficult to have a paper published in one of the specialist journals unless it is mathematical. The contribution of British economists has been less significant but nevertheless has not been insubstantial, and they too have tended to explore legal concepts or procedures with abstract, theoretical models, not easily accessible to those unfamiliar with the discipline. That should be contrasted with the work of, for example, Bill Bishop and Brian Cheffins, two Canadians who have straddled the two disciplines and, through a careful "translation" of concepts, have generated particularly important insights for British scholars working in, respectively, tort $^{28}$ and company law. ${ }^{29}$

The changes that I have described may be attributed, to some degree, to developments in the academic environment and the market forces which related to research. Take first the labour market. The "radicals" whose career ambitions in the 1970s and early 1980s might seem to have been thwarted by their advocacy of interdisciplinary studies had now, as a result either of "natural" promotion progression or of eventual recognition of their intellectual contributions, become part of the academic establishment. ${ }^{30}$ Interdisciplinary scholars of the next generation were, therefore, unlikely to be disadvantaged.

The introduction, and increasing importance, of the Research Assessment Exercise has had a mixed impact on legal interdisciplinary studies. In some social sciences - economics is a notable example - work on the law is seen as "applied" research, which is not rated so highly by the evaluating panel as pure, "theoretical" work. This has clearly deterred some economists from engaging in collaborative work with lawyers. ${ }^{31} \mathrm{My}$ impression is that the experience in law has been almost exactly the opposite. The panel has regarded interdisciplinary research as a "broadening-out" rather than a "narrowing-down" and, given also its policy relevance, has, it seems, rated work of this kind as particularly valuable. One consequence has been the recruitment of social scientists into some law departments to boost research performance. ${ }^{32}$ Another,

27 ESRC Review, above n 2, at p.37.

28 In a number of papers, but perhaps most notably in Bishop, "Economic Loss in Tort" (1982) 2 Oxford JLS 1.

29 Cheffins, Company Law: Theory, Structure and Operation (1997).

30 Thomas, above $\mathrm{n} 15$, at $\mathrm{p} .2$.

31 Ogus and Amass, above n 19, at p.22.

32 Hillyard and Sim, "The Political Economy of Socio-Legal Research" in Thomas (1997), above n 2, at p.64. 

Law

more controversial, outcome has been that lawyers have been given greater control of the interdisciplinary agenda. ${ }^{33}$

Perhaps the most significant "market" influence on interdisciplinary work has been the growth of interest in, and readiness to fund, socio-legal research displayed by UK government departments, much of it allocated on the basis of competitive tendering. True, as some critics have observed, ${ }^{34}$ at the height of the Thatcherite period, there was a "blurring of the distinction between consultancy and research", with private sector institutions winning contracts for short-term, and largely numbercrunching, research exercises. The phenomenon was allied to the faith shown in, and dependence on, quantifiable variables and audit as policy tools. ${ }^{35}$ But focussing on this aspect of government strategy should not be allowed to detract from what else has occurred, particularly recently. The Home Office has always been a significant sponsor of interdisciplinary research in crime and related areas and between 1988-91 devoted about 40 per cent of its $£ 4.826 \mathrm{~m}$ budget to externally-conducted research on sociolegal topics. ${ }^{36}$ It has been a different story with regard to the Lord Chancellor's Department. Traditionally suspicious of research, especially social science research, until relatively recently it has done little to encourage interdisciplinary studies. ${ }^{37}$ A major change occurred in 1996, following the transfer of a leading civil servant to the LCD from the Home Office. A new and well-funded research programme, with its own secretariat and covering broad areas of the legal system, was then launched. ${ }^{38}$ And to this may be added perhaps the most significant development for policy-orientated socio-legal research: the readiness of government to engage in pilot studies of legislative reforms before they are implemented.

Of course, the Economic and Social Research Council (the successor to the Social Science Research Council) has continued to support interdisciplinary legal studies (spending $£ 6.727 \mathrm{~m}$ on socio-legal research between 1985 and $1991^{40}$ ). But, as a consequence of a general governmental concern that research was too theoretical, ${ }^{41}$ there was a major development in the direction of policy relevance. Now "research users" were to play a significant role in both the selection and the evaluation of

33 Ibid, at p.65.

34 Ibid, at pp.56-7.

35 Power, The Audit Society: Rituals of Verification (1997).

36 ESRC Review, above $\mathrm{n} 2$, at $\mathrm{p} .32$.

37 When I and colleagues were, in 1985 , awarded a grant of some $£ 400 \mathrm{k}$ to investigate divorce mediation, this was the largest project hitherto funded by the LCD. We quickly became aware that the departmental officials lacked experience in dealing with academic researchers.

38 LCD, Research: The Way Forward (1996). For current developments, see the website www.open.gov.uk/lcd/research/introfr.htm.

39 The outstanding example is the Family Law Act 1996 and research carried out on the piloting of information meetings and mediation. Recently the Lord Chancellor announced that the government did not intend to implement Part II of the Act and it is clear from the statement that the research of the piloting by the Centre for Family Studies at the University of Newcastle upon Tyne was the main reason for that decision.: HL Written Answer 17 June 1999.

40 ESRC Review, above $\mathrm{n} 2$, at p.30.

41 Office of Science and Technology, Realising Our Potential (1993, Cm 2250). 
funded projects. ${ }^{42}$ This may have had a constraining influence on the type of funded research undertaken and for that reason, as we shall see, has been vigorously criticised. On the other hand, it has helped to ensure both that the research is related to key policy issues of the day ${ }^{43}$ and, because potential users are involved, that it will have a higher profile; it also increases the likelihood that the findings will significantly influence policy-making.

The fact that there has been an increased engagement in interdisciplinary work that is policy-orientated does not mean that the "high theory" end of the spectrum has been neglected. There has been a seemingly endless supply of publications applying to law various aspects of post-modernism: feminism and gender studies; semiotics and autopoiesis; socio-biological analysis; and so on. ${ }^{44}$ Some of this is written in uncompromising language that is largely incomprehensible to those outside the discourse of the particular discipline. It may involve some development in the theoretical understanding of law, but it makes a relatively small contribution to issues that have to be addressed by policy-makers. There is, too, a stream of postmodern thought which, like some aspects of critical legal studies to which it succeeds, adopts provocatively ${ }^{45}$ an almost nihilistic approach to the law: after so much "deconstructing" little is left in law which is meaningful. I, nevertheless, sense that there is not the same distancing from empirical work that characterised the earlier period; nor, for the majority, is there an unwillingness to engage in legal policy debate. ${ }^{46}$

Any rapprochement between high theory and empirical studies has, however, not inhibited sharp and bitter criticism of the institutional developments which I have described above. The Research Assessment Exercise is castigated on the grounds that "it is impossible because the tools for measurement do not exist", wasteful of resources (the 1992 exercise was estimated to have cost over $£ 13 \mathrm{~m}$ ) and, because it increases competition, tends to colonise "the space for independent and critical scholarship" by "a disciplinary project of classification, categorisation and assessment". ${ }^{47}$ Then the institutional changes to the public funding bodies (the expansion of government department sponsored research and the introduction of "user" evaluation") have been seen as threatening the independence of academic research.

"The danger is ... that the expectation of the sponsor is not simply that the research be conducted, but that it does indeed support a policy line and

42 A Socio-Legal Research Users' Forum was established in 1994. On this, see Partington, "Socio-Legal Research In Britain: Shaping The Funding Environment" in Thomas (1997), above n 2, at pp.24-27.

43 As an example particularly pertinent for this journal, I should mention the award of $£ 134,107$, for the period 1998 to 2000, to researchers at the University of Ulster to undertake an evaluation of the alternative criminal justice system in Northern Ireland.

${ }^{44}$ For a general overview, see Douzinas and Warrington, Postmodern Jurisprudence: the law of texts in the texts of the law (1993).

45 "CLS has been a persistent provocation to mainstream legal scholarship from its earliest guise as variants of phenomenology and critical social theory to its later inclusions of postmodernism, feminism and anti-racism": Fitzpatrick, "Distant Relations: The New Constructivism in Critical and Legal Studies", in Thomas (1997), above n 2, at p.146.

46 Cf O'Donovan, "Fem-Legal And Socio-Legal: An Incompatible Relationship", in Thomas (1997), above n 2, ch.6.

47 Hillyard and Sim, above n 32, at pp.52, 62, and 63. 

Law

advocates as powerfully as possible a pre-determined interest. Indeed the research may be evaluated by the sponsoring organisation in terms of how effectively this is done." 48

More generally, the accusation is that the phenomena of competitive tendering, short-term research employment contracts and the like have led to

"The commodification of research . . . a shift within academe from "publication" as the currency unit of values to "grants" . . . the monetarisation of intellectual labour." 49

It will be clear from my earlier remarks that I consider much of this criticism to be misplaced. Indeed, I would argue that legal interdisciplinary studies have been able to flourish in the later period precisely because of the conditions in the market, or quasi-market, for such research. Let me conclude this short paper by expanding on the theme.

\section{UTILITY AND DISUTILITY}

First, we need to be reminded that law is predominantly a professional discipline, without its own scientific methodology. By that, I mean that it is basically a body of knowledge and techniques used by practitioners to organise social and economic life. The consequence is that academic lawyers have to come to terms with the (not always welcome) fact that serious attempts to understand and evaluate the content of the law must necessarily come from other, predominantly social science disciplines. ${ }^{50}$

How then can we, and others, determine the utility or disutility of how we use those other disciplines? As indicated at the beginning of this paper, there is a spectrum from, at the one end, "high theory" to, at the other, empirical, policy-orientated investigation. There is utility to be derived throughout the spectrum, but that utility is maximised at the point of optimal mix. Although opinions may differ in identifying that point, my account of the evolution of legal interdisciplinary study in Britain suggests that in the first period too much research was undertaken too far from it But that, in the second period, the market and other institutions which influence academic output were so deployed as to generate activity much closer to the optimal.

To understand the latter development, we need to explore how the demand and supply sides of the market for interdisciplinary research are likely to operate. Since law is to a large extent dominated by professional practice, we would expect that as the relevant decision-makers become increasingly aware of the value of interdisciplinary work so they will generate a demand for policy-orientated outputs, with the concrete benefits that these may generate. Will such demand be adequate relative to what is socially desirable? The answer is probably, no. As is well known, information including the outcome of scientific research - has public good aspects, since many users are able to "free-ride" on those who pay for it. Add to this that academic lawyers are unlikely to derive much non-financial utility from engaging in empirical work -

48 Lee, "Socio-Legal Research - What's the Use?", in Thomas (1997), above n 2, at $\mathrm{p} .87$.

49 Hunt, "Governing the Socio-Legal Project: Or What Do Research Councils Do?" (1994) 21 Journal of Law and Society 520, at pp.520-521.

50 Balkin, "Interdisciplinarity as Colonization" (1996) 53 Washington and Lee LR 949. 
"Legal academics feel about empiricism the way that most men feel about housework: they are extremely glad that someone else does it" ${ }^{1}$

and we have a case of market failure. We need to use public institutions to fund policy-orientated, particularly empirical research. Those public institutions, if they are doing their job properly, will seek to reflect the demand for interdisciplinary work which thus should have a bias not only towards policy-orientation but also with an emphasis on dissemination and the communicability of the results of the research.

What then of "high theory"? Clearly, the demand side of the market is here even more problematic. Although those engaging in applied research will, to a greater or lesser extent, require theory in which to ground their hypotheses, they can expect to "free-ride" on the general availability of books and articles by theorists. And the other benefits of theoretical work are even more diffusely spread. On this basis, given the inadequacy of returns, we should expect a significant under-supply of such work. Does this suggest the need for public institutions to inject additional resources to encourage theoretical, as well as empirical work? I would argue that it does not for, as my account above reveals, there has not been - even in the earlier period - a problem on the supply side of this market. There are, it seems to me, two main reasons for this. First, it appears that many scholars derive substantial non-financial utility from theoretical work. ${ }^{52}$ Secondly, security of tenure of employment, when achieved, enables them to pursue longer-term projects of the kind necessary for work of this kind, although to some extent this may be undermined by pressures from the research assessment exercise.

To summarise: the observable utility of interdisciplinary studies of law has increased within the last decade or so. To some degree, the development may be attributed to changing conditions in the market for research and the response of public institutions to failures in that market.

51 Ibid, at p.969.

52 Landes and Posner, "An Economic Analysis of Copyright Law" (1989) 18 Journal of Legal Studies 325, at pp.331-333. 